\title{
An Assessment of the Relevance of Mapping and Sampling of Land-Use Types on Groundwater Quality in Apapa Local Government Area, Lagos State, Nigeria
}

\author{
Agbebaku, H. U. \\ Department of Environmental Sciences and Toxicology, Faculty of Sciences, National Open University of \\ Nigeria, Jabi-Abuja \\ Corresponding Author: *hagbebaku@ noun.edu.ng
}

https://doi.org/10.36263/nijest. 2021.02.0234

\begin{abstract}
The paper examined the assessment of the relevance of mapping and sampling of land-use types; residential, commercial and industrial on groundwater quality in the Apapa Local Government area of Lagos. Mapping of an area provides information, delineation, features and interpretation about an area while sampling revealed detailed analyses about a-cross-sections of the problem identified procedures and proper solutions. There exists a correlation between mapping and sampling of groundwater quality of the land use types in Apapa. The objective of the study was to examine the relevance of mapping and sampling on its effects on groundwater quality of the 3 most land-use types in Apapa. Data for this study were obtained from primary and secondary sources. Primary data were obtained from mapping of the aerial and ground features of the study area and collection of water samples from 30 hand-dug wells. These samples were analysed in the laboratory to ascertain the states of physical and chemical parameters of the 30 sampled points. The techniques of field studies and analyses of mapping and laboratory experimentation of water samples were used for the study. The results show that mapping of the aerial extent and ground features is relevant to sampling collection because mapping is essentials and provides a fulcrum for physical and human features to be examines where samples of an area or events is to be made. The study recommended that at regular intervals, mapping of an area extent and ground features of sampling points of water sources should be done and made available to examine water quality as recommended by $\mathrm{WHO}$, since flow lines of ground water movement convey pollutants which inferably determine the contamination of water sources. This paper calls for further research of mapping and sampling in other major land use types in other Local Government areas of Lagos State, Nigeria.
\end{abstract}

Keywords: Assessment, Groundwater Quality, Land-Use Mapping, Sampling, Relevance and Apapa, Lagos

\subsection{Introduction}

Mapping connotes plotting of aerial and ground diagrams and interpretation through the techniques and tools of geo-informatics such as geographical information system (GIS), global positioning system (GPS) and remote sensing (RS). Sampling connotes the act of gathering, observation, processes and examination of collected samples. The techniques of mapping and sampling are vital to experimental research in varied discipline and mainly in the physical arm of geography, in the sense that it's allow for field observation, measurement and samples analyses. The techniques of the use of geographical information system (GIS), global positioning system (GPS) and remote sensing (RS) to access aerial extent and land information and imagery of places, objects and events are fundamental in the sub-field of hydrological geography (Cannor, Kralewski and Hillson, 1994; Adekunle, 2007; Uluocha, 2015; Edobor, 2016). The combination of the tools of mapping and sampling such as geographical information system (GIS) global positioning system (GPS) and remote sensing (RS) to access, acquire and analyze data in known as geo-informatics. Geo-informatics is a computer based set of procedures that capture, store, manipulate, edit, retrieve, analyse, mode and display data with spatial characteristics. In addition, the techniques enable users to interactively query data-sets, analyse 
spatial information and present results of these operations into maps, tables, samples and organized data-sets (Aronoff, 1989; Iyun, 1990; Wesrcott, 1999; Okonko, Adejoye, Ogunusi, Fajobi and Shittu, 2008; WHO, 2009; Eludoyin, 2010; Uluocha, 2015; Edobor, 2016).

The advent of modern technology and proliferation of the uses of geo-informatics tools in the early $19^{\text {th }}$ Century extended its use of operations into diverse fields of studies for quality research such as; academic research, resource management, environmental impact assessment, cartography, remote sensing, urban planning, criminology, geographic history, logistic, medicine and marketing (WHO, 2009; 2015; Adekunle, 2007; Edobor, 2016; Agbebaku, 2019). In physical Geography, such as the studies of hydrology, geomorphology, climatology, biogeography, cartography, geographical information system and remote sensing, the techniques of geo-informatics have helped researchers to achieve wider and ground-breaking results in their fields of researches. For instance, in hydrological research, under surface and groundwater quality of an assessments and analyses of physical, chemical and biological parameters, the tools of geographical information system(GIS), global positioning system(GPS) and remote sensing(RS) via the techniques of plotting, collation and production of maps and sampling collations have helped the ease the processes of data acquisition and plotting, samples collection and classification and laboratory analyses of results (Ojeifo and Kadiri, 2008; Akotenyon, 2011; Oluleye and Rilwani, 2011; Soladoye and Agbebaku, 2015; Uluocha, 2015; Edobor, 2016; Agbebaku, 2020).

The studies of Chapman, 2004; Adelegun, 2006; Strahler and Strahler, 2006; Eludoyin, 2010; Akotenyon, 2011; Soladoye and Agbebaku, 2015 submitted that the techniques of GPS, GIS and RS plays vital roles in assessment and analysis of surface and groundwater quality just as in the case of this study which focus on the relevance of mapping and sampling of land-use types on groundwater quality of hand-dug wells in Apapa Local Government area of Lagos State. Furthermore, the tools of geo-informatics aid the collection and analysis of; water samples, spatial geographical locations and coordinates, depth and height of wells, distance from sewage and descriptive modes of water samples collected from the hand-dug wells. In assessment of groundwater quality and land use types, parameters from the soil and water samples must be carried out. For result of water samples to be ground-breaking, physico-chemical and biological parameters and laboratory analyses need to be carried out. These same procedure is applicable for soil analysis; test samples from the soil need to be collected, tested and analysed (Chapman, 2004; Adelegun, 2006; Strahler and Strahler, 2006; Akotenyon, 2011; Akotenyon and Soladoyin, 2011; Soladoye and Agbebaku, 2014; Agbebaku, 2020). In all of these processes, the techniques of geo-informatics come to plays, more so the techniques give the researcher a focus of belonging as attention will be drawn to a particular location, history, procedures and results of the activities and problem in question. In addition, the tools enable us to have sound knowledge of the aerial extent and location in terms of defining the problems, purpose, scope and methods of data collection and analysis. Furthermore, the tools help to provide a guide and direction to the problem identify in the sense that it provides physical, cultural and scientific methods and information for the research to be achievable (Iyun, 1990; Wesrcott, 1999; Brooker, Rowlands, Haller, Savioli and Bundy, 2000; Campbell, 2002; Soladoye and Agbebaku, 2014; Edobor, 2016).

Groundwater quality of the earth surface is a function of the land use types, resulting from the activities of man (anthropogenic) that generates contaminants from land use types such as industrial, commercial and residential capable of negative impacts on water source and quality. On the other hand, groundwater quality it's a function of how finest, cleanest and polluted of the state of the various segments of the soil aquifers (Strahler and Strahler, 2006; Agbebaku, 2014; Soladoye and Agbebaku, 2015). The nature of soil types, structures and textures (matrix) to a great extent determines how slow or fast the soil can be contaminated, that is seepages infiltrate into the soil. In addition, the flow of contaminants circulates laterally and horizontally from one aquifer to another. The rate of pollution of groundwater quality is a function of the matrix and the nature of aquifer; as rocks of sedimentary origin have high porosity and permeability than igneous and metamorphic rocks which allow for more flow of pollutants or substances. Furthermore, the slope of the water table plays a vital role in groundwater quality and movement of water. Ground water types such as water from hand-dug wells and bore-holes drillings must penetrate the water table for regular supply. This is to optimize their potential flow and attain water quality (APHA. 1992; Chapman, 2004; Christopherson, 2007; Akotenyon, 2011; Agbebaku, 2014; Soladoye and Agbebaku, 2015). 
The studies of Aderibigbe, Awoyemi and Osagboni (2008), states that the use of groundwater has increased significantly in the last 2 decades due to its widespread occurrence and overall noble quality owing to the techniques of Geo-informatics. These scholars added that the contribution from groundwater is vital; because about two billion people depend directly upon aquifers for drinking water, and 40 percent of the world's food is produced by irrigated agriculture that relies largely on groundwater. Groundwater is the water below earth's surface of all the water that falls on land as rain or snow, about $1 / 3$ runs of the surface into streams and rivers and another $1 / 3$ evaporates or absorbed by plants. The rest drips or percolates down through the soil and rocks and becomes part of the groundwater resources. Groundwater is the part of the sub-surface water that fully saturates the pore spaces in bedrock, regolith, or soil, and so occupied the saturated zone (Akotenyon and Soladoyin, 2011; Strahler and Strahler, 2006). Furthermore, the volume of water in the soil is related to the size of the drained as well as the factors like the processes of precipitation, infiltration, evaporation and transpiration. Soft, un-polluted and un-contaminated water infiltrates more easily than hard, polluted, and contaminated water. Infiltration of groundwater is more suitable with highly permeable soils matrix type with good natural or constructed drainage and where the annual loading rate varies between 3.0 to 150.0m/yr (Adelegan, 2004; Strahler and Strahler, 2006; Gohil, 2007; Akoteyon and Soladoyin, 2011).

Prior to this study, there have been a lots of mapping of Apapa aerial extent and sampling of groundwater collections and experimentations and analyses to ascertained their physical and cultural features plotted as well as results of water samples collections and collated on water quality in recent time (Akonteyon, 2011; Akotenyon and Soladoyin, 2011; Agbebaku, 2014; Soladoye and Agbebaku, 2015). This is due to increase in socio-economic activities and influx of human population in Apapa. Apapa and its environs happens to be one of the urban areas of the state where about $75 \%$ of socioeconomic (industries) activities are concentrated and explored. With these activities, the influence of bacteria, micro-organisms, pesticides, chemical, lead, heavy metals and nitrate is so high in these areas owing to the pace of concentration of socio-economic activities. Physico and chemical parameters such as colour, odour, tastes, turbidity, temperature, heavy metals and bacteria virus is also high owing to the above factors. Waste generation irrespective of its types and kinds (industrial and domestic) is relatively high as a result of high population concentration and pace of industrial activities. These activities and actions propels a high level of linkage and interactions between the quality of surface and ground waters, mostly with the flow of chemical and biological parameters of the activities of gasoline, petro-chemical, mining and industrial activities and waste disposal on surface water which metamorphosed into groundwater contamination (Adekanbi, 1979; Adelegan, 2004; Strahler and Strahler, 2006; Gohil, 2007; Akonteyon, 2011; Agbebaku, 2014, 2020).

Based on the above, there is a direct links between land use types and water quality of a place as one and or a combination of the below indices have direct links on water quality and negative effects on ground water quality. These groundwater pollutants could be in the form of; (a)pathogen nutrient (bacterial, pathogenic viruses, protists) (b)sedimentation in water (silt, clay, acid precipitation, chemical, nylon, mineral) (c)habitat alteration (urbanization, road construction, agriculture, industrial) (d)metals in water (mercury, lead, arsenic) (e)pesticides (gamalin, didimax) and (d)oxygen depleting substance (offensive perfumes, carbon-monoxide). Furthermore, groundwater pollution can result from one and a combination of the various sources (a)agricultural and industrial practices (b)hydrological modification and (c)municipal uses while the processes of groundwater pollution can be from one or a combination of any of; (a)sedimentation (b)eutrophication (c)acidification (d)microbial contamination (e)toxic chemical and (f)thermal pollution (Adekanbi, 1979; Adelakun, 2004; Strahler and Strahler, 2006; Akotenyon, 2011; Wright and Boorse, 2011; Akotenyon and Soladoyin, 2011; Agbebaku, 2014; Soladoye and Agbebaku, 2015). In view of the above, there is need for mapping of the spatial patterns of land use types of the activities of man mainly in high prowl areas like Apapa where high pace of socio-economic activities takes place and sampling of water collection for laboratory analysis from such area and the linkage between the two variables to ascertain groundwater quality for man uses. This informed the reason for this research as the research gap is meant to ascertain an assessment of the relevance of mapping and sampling of land-use types on groundwater quality of hand-dug wells in Apapa Local Government area of Lagos state. In order to achieve this, the objective of this paper is to examine the relevance of mapping and sampling of landuse types on groundwater quality in Apapa Local Government area of Lagos State. 


\subsection{Methodology}

\subsection{Study area}

The study area is Apapa Local Government area of Lagos State. This area lies approximately between Latitude $60^{\prime} 22^{\circ} \mathrm{N}$ and $60^{\prime} 24^{\circ} \mathrm{N}$ and Longitude $30^{\prime} 20^{\circ} \mathrm{E}$ and $30^{\prime} 40^{\circ} \mathrm{E}$ and also a GPS coordinates of 6 27 ' 103" and $321^{\prime}$ '847'. Apapa Local Government area shares boundaries to the north and west with Lagos Mainland and Ajeromi-Ifelodun Local Government Areas of Lagos State respectively. To the east and south are water bodies that are parts of the Lagos lagoon and the Atlantic Ocean. It has a total land area of $38.5 \mathrm{~km}^{2}$ of which $13 \mathrm{~km}^{2}$ is water (Lagos Bureau of Statistics, 2011). The study area is a hub of socio-economic activity. It is a vast expanse of manufacturing industries. Various industries, ranging from soap making to plastic, paint and cement production, are within the study area. The reserve tanks of major oil companies are in the area. The two major shipping ports in Nigeria namely the Apapa and Tin Can ports are also located there. There are clusters of petrol stations, shopping malls and several other businesses in the area. Several government establishments, including three military barracks are in Apapa. To get primary data, water samples used in the study were collected and analysed. Both descriptive and ANOVA statistical analyses were used for the study.

The study area shares boundaries to the north and west with Lagos Mainland and Ajeromi-Ifelodun Local Government Areas of Lagos State respectively. To the east and south are water bodies that are parts of the Lagos lagoon and the Atlantic Ocean. It has a total land area of $38.5 \mathrm{~km}^{2}$ of which $13 \mathrm{~km}^{2}$ is water (Lagos Bureau of Statistics, 2011). The study area is a hub of socio-economic activity. It is a vast expanse of manufacturing industries. Various industries, ranging from soap making to plastic, paint and cement production, are within the study area. The reserve tanks of major oil companies are in the area. The two major shipping ports in Nigeria namely the Apapa and Tin Can ports are also located there. There are clusters of petrol stations, shopping malls and several other businesses in the area. Several government establishments, including three military barracks are in Apapa. To get primary data, water samples used in the study were collected and analysed. Both descriptive and ANOVA statistical analyses were used for the study. The area of study is Apapa Local Government of Lagos state. The diagrams below show the relevance of GIS and GPS coordinates of mapping and sampling locations in the study area. For instance, Figure 1 shows map of Lagos State, inset is Apapa Local Government area while Figure 2 shows cadastral map of Apapa and its bounder locations. Furthermore, Figure 3 shows the varied major land-use types of Apapa Local Government Area while Figure 4 shows the geographical spread of the 30 sample locations of hand-dug wells of the 3 major land use types of the study area.

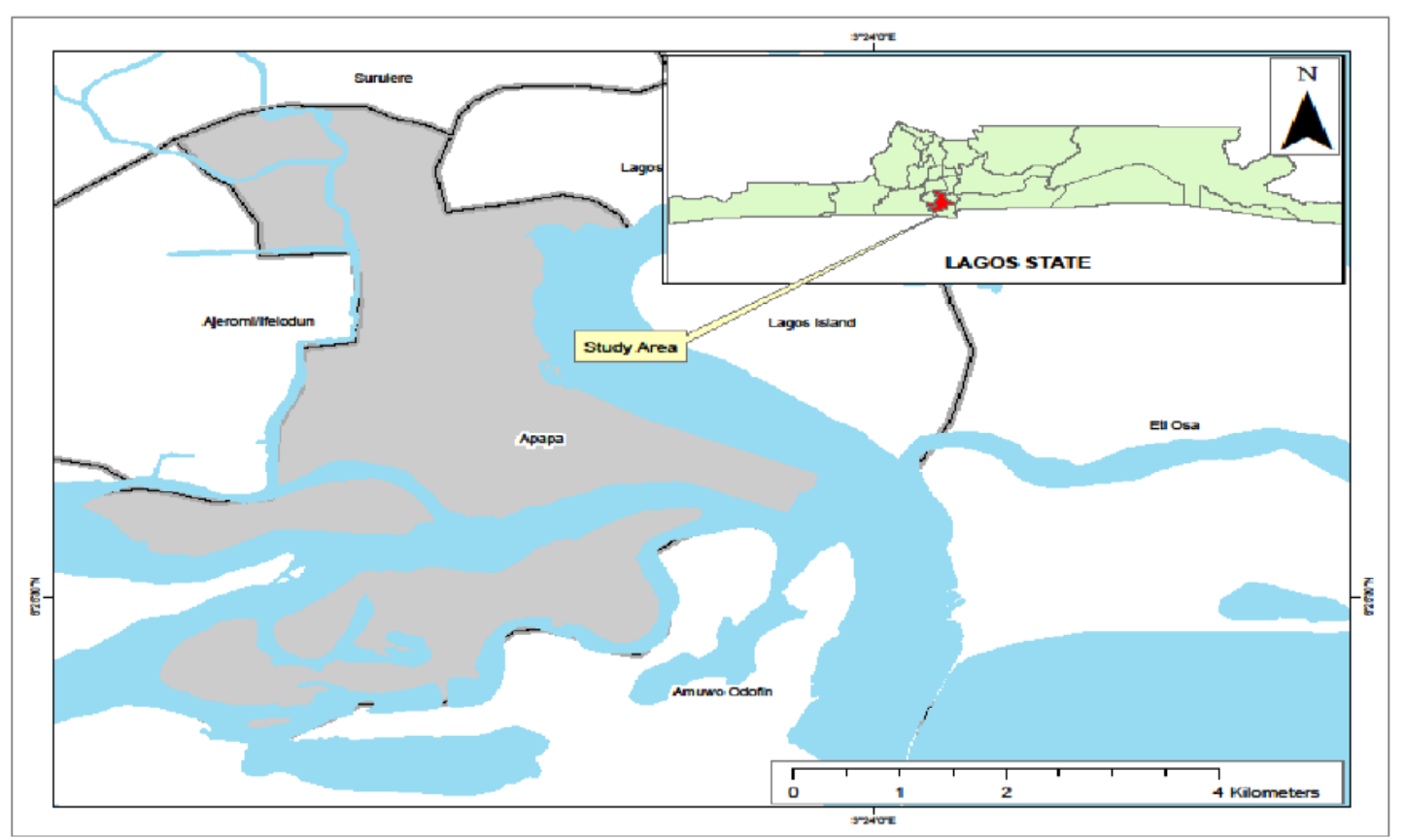

Figure 1: Map of Lagos State and Study Area Source: GIS and Cartography Unit, LASU (2020) 


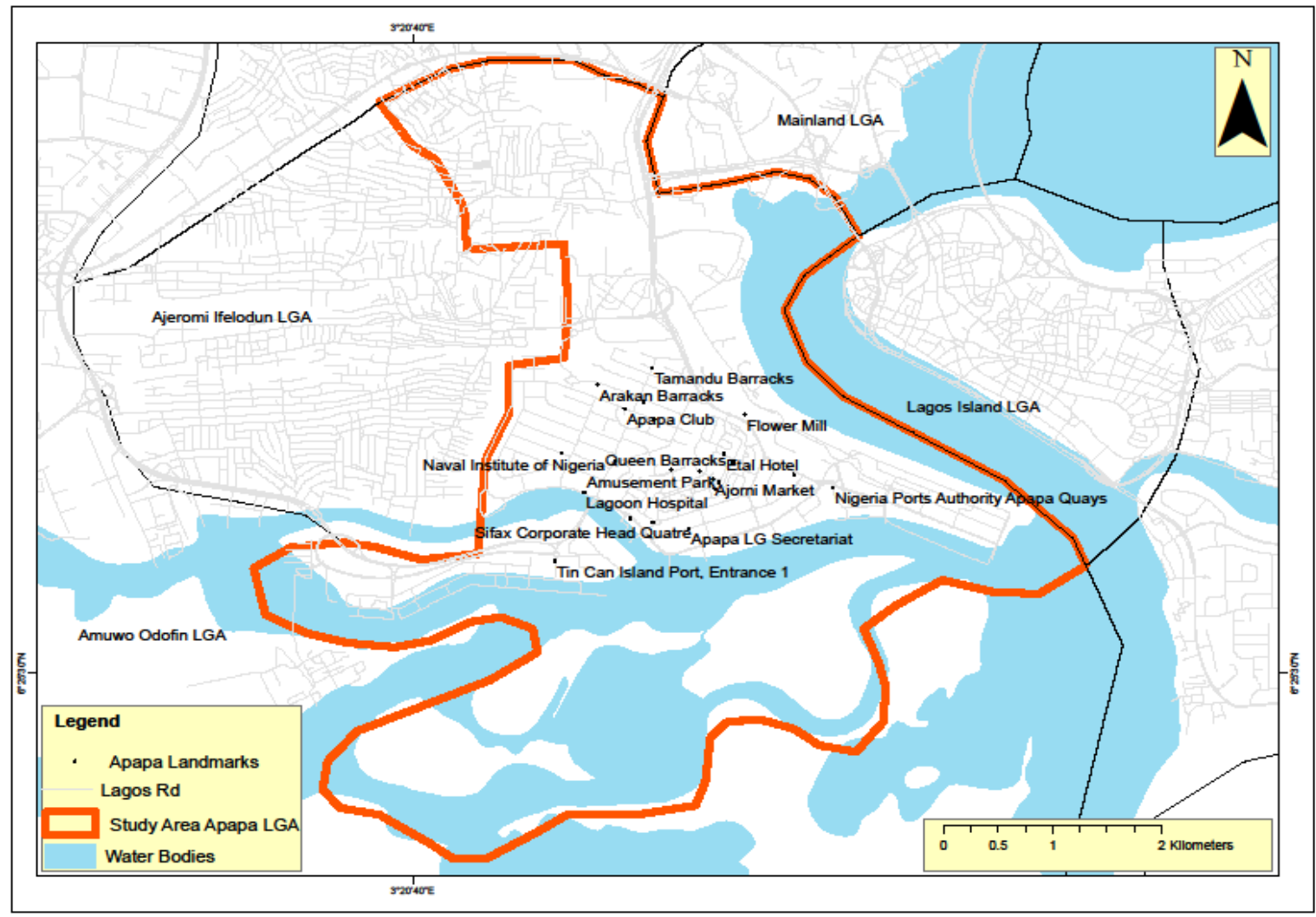

Figure 2: Cadastral map of Apapa and socio-economic activities of the Local Government Area Source: GIS and Cartography Unit, LASU (2020)

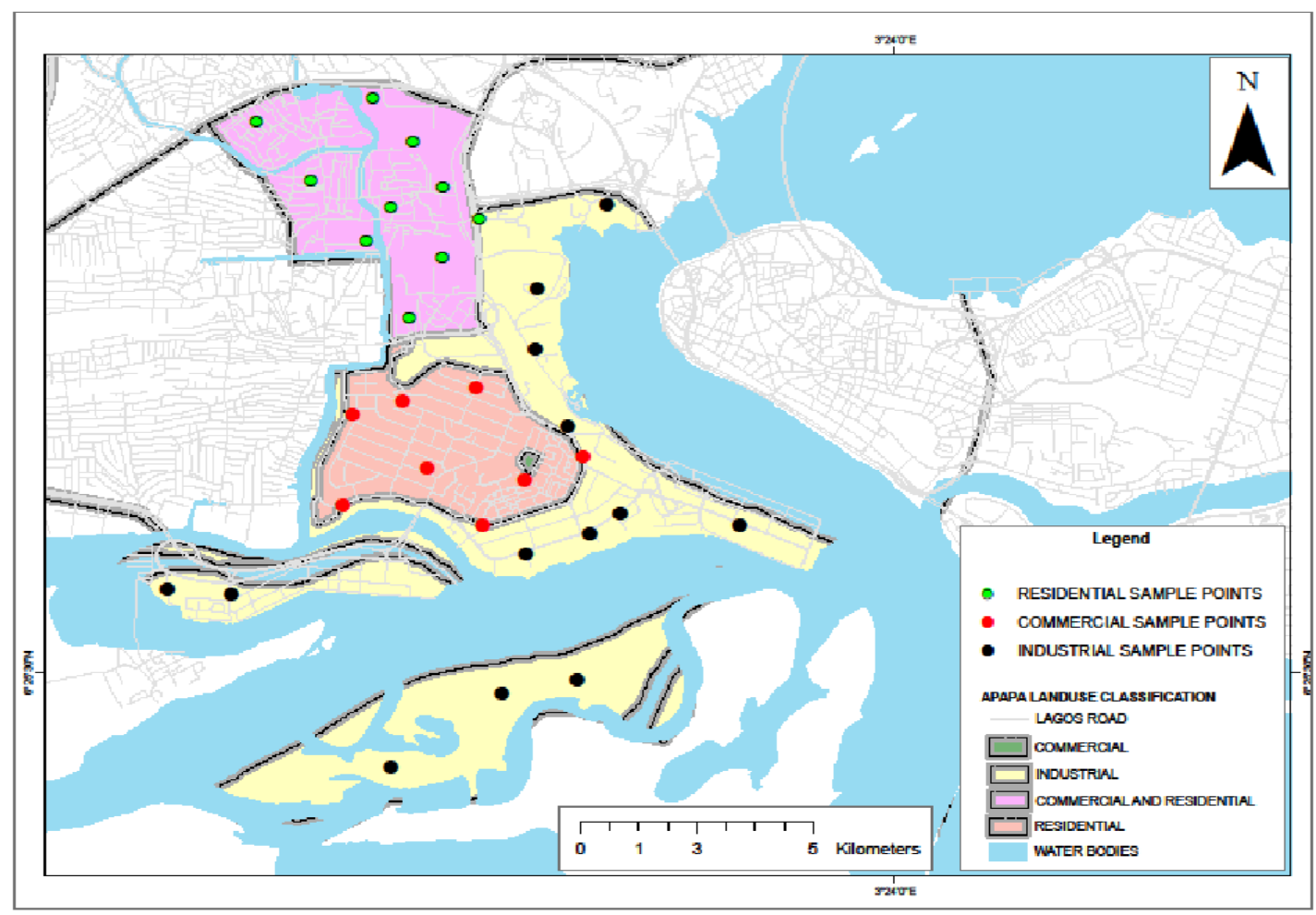

Figure 3: Mapping of Apapa and varied major land-use types of the Local Government Area Source: GIS and Cartography Unit, LASU (2020) 


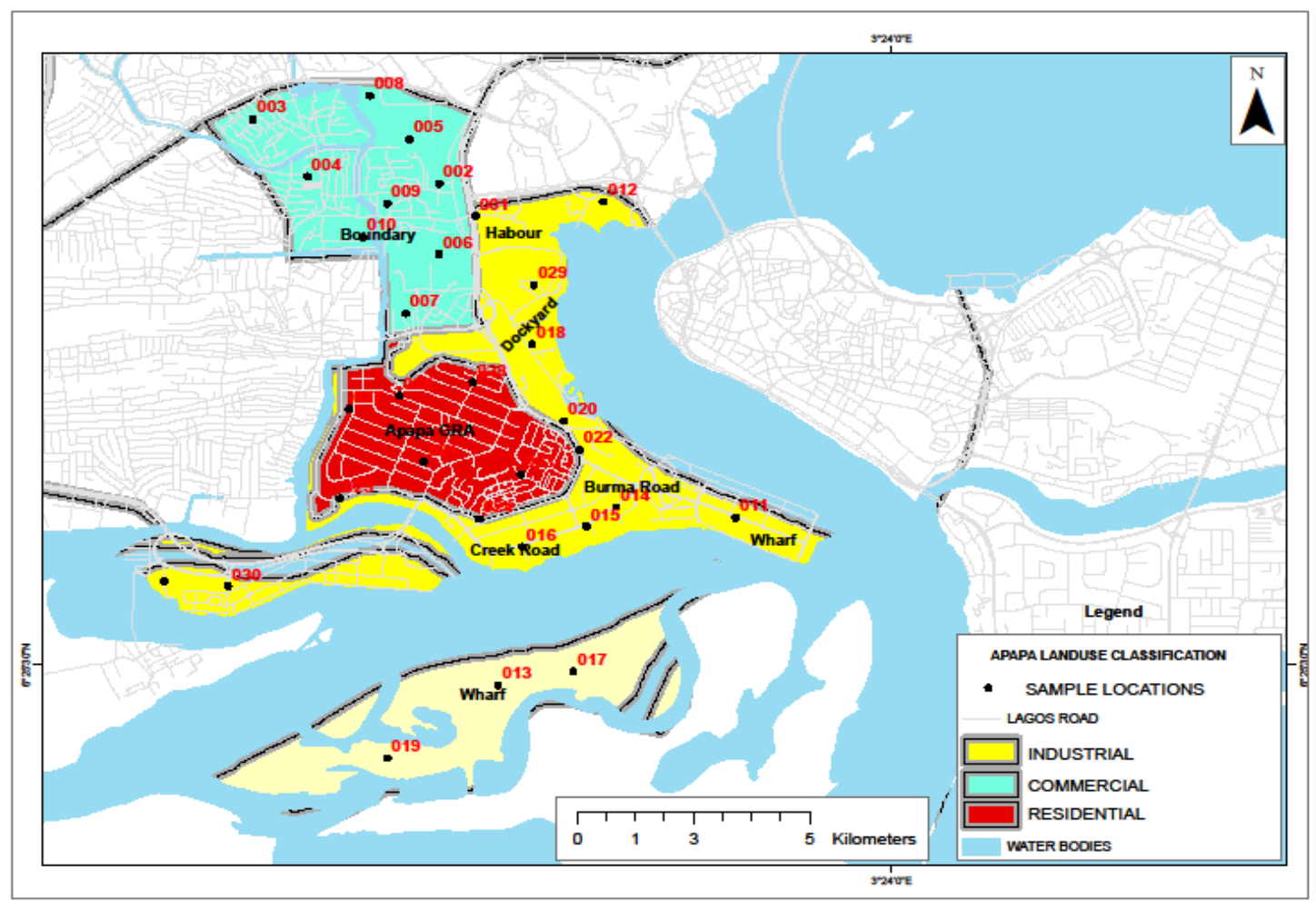

Figure 4: Mapping of the geographical spread and coding of 30 sample locations of the 3 selected land use types of the Study Area

Source: GIS and Cartography Unit, LASU (2020)

\subsection{Method of Study}

Mappings for this study were generated and sourced from field-work survey of the study area. These maps were produced by a GIS expert in the studio of Geographical Information System and Cartography unit of the department of Geography and Regional Planning, Lagos State University, Ojo, (LASU). These were done in line with the standard procedures for map generation and production. For this study, a combination of the tools of data mapping such as; open-source, onpremises, alooma and cloud-based were adopted for generation of the maps in this research while the 6 processes of mapping steps such as; goals determination, identification of output, identifying customers, identifying input, identifying the components process and identifying the process suppliers were all observed and maintained in mapping of the study area. The maps generation from these tools and processes were presented in Figures 1 to 4 to ascertain the essential features of the study area. Figures 1 to 4 (a) shows maps of Lagos state and the study area (b) cadastral map of Apapa and socioeconomic activities of the Local Government area (c) Apapa and varied major land use types of Apapa Local Government area and (d) mapping of the geographical spread and coding of 30 sample locations of the 3 selected land use types of the study area respectively.

Water samples were collected from the sample locations (Figure 4) and analysed in the laboratory following American Public Health Association (APHA, 2005) the recommended standard procedure for water quality. The thirty (30) hand-dug wells selected for study were from 3 major land-use types namely commercial, industrial and residential land uses. On the whole, ten of the wells were within the commercial category while twelve and eight were from the industrial and residential respectively. Each well was allocated a number for reference and identification purposes. The land use types are indicators of the level of anthropogenic activities in each area. Classifying the study area into strict land use zones was difficult because of the characteristic land use mix feature of the area. The areas designated in this study as commercial are used mainly for commercial purposes such as fuel depots and shopping areas. The industrial areas are distinct and comprise the places where factories are. However, the residential areas are mixed as they include locations that are used largely for 
administrative but as well as commercial purposes. Included are the military barracks, churches and government offices.

The physical parameters considered include $\mathrm{pH}$, turbidity, dissolved oxygen (DO), total dissolved solid (TDS), total suspended solid (TSS) and electrical conductivity (EC). The chemical parameters tested include major cations such as magnesium $(\mathrm{Mg})$, calcium $(\mathrm{Ca})$, sodium $(\mathrm{Na})$ and potassium $(\mathrm{K})$. Also included are major anions namely nitrate (NO3), chloride (Cl), sulphate (SO43-), and phosphate (PO43-). Statistical methods of correlation and one-way analysis of variance (ANOVA) were adopted for use in the study. Correlation analysis was used to identify relationships between water parameters. ANOVA was used to determine significant differences in groundwater parameters across land uses at $0.05 \%$ level of significance. The Scheffe post hoc test was conducted to identify the land use groups per parameter that differ. The land use groups were identified as Group 1 (Commercial), Group 2

(Residential) and Group 3 (Industrial). To verify the relationship between the examined groundwater variables, laboratory data were subjected to bivariate correlation analysis. With the aid of SPSS, analysed results were presented with correlation matrix table. Table 3.3 shows the correlation matrix of the major physicochemical parameters of the land used types in Apapa. However, the study was restricted with the used of geo-informatics tools of GIS and GPS together with soil samples collected

from the field of study for analyses. Samples and analysts on biological parameters were left out.

\subsection{Results and Discussions}

Results for this study were presented in Tables 1, 2 (2a-c) and 3 respectively. Prior to these results, Figures 1 to 4 shows the relevance of mappings and plotting's of the study area for the ease of sampling collections; the maps of Apapa and Lagos state, cadastral plotting of Apapa and socioeconomic activities, Apapa and varied major land-use types and geographical spread and coding of 30 sample locations of the 3 selected land use types respectively were all spelt out. These varied maps enable the study to have a glimpse of the aerial extent, physical and cultural features about Apapa and defining the problems, purpose, scope and methods of data collection and collation. Table 1 shows the essentials of geographical information system (GIS) mapping of the area extent as presented in Figures 1 to 4 respectively while global positioning system (GPS) enables the coding of the 30 sampling locations of hand-dug wells as in the case of this study. In additions, Table 1 shows details glimpse of the attributes of GIS and GPS of the 30 water samples collection in each of the major land use types of the study area tagged commercial, residential and industrial. More so, the tools of GIS and GPS enable the examiner to ascertain results in each of the sample locations of the hand-dug wells such as the features of; sample location point, sample code, geographical location, coordinates, depth, height, distance and descriptive mode of each of the wells examined as presented in Table 1. Furthermore, the analysis in sequential order from Table 1 revealed that, the highest depths of wells from the Commercial land-use type (tagged C1-10) are those from Queen Barrack, Boundary Areas with depth feet's ranging from 18.9 to 21.4 .

In addition, all wells in this land use type are constructed with concrete materials and are uncovered, though there were indicators that they were constructed with covers top. The difference in height range is 9.5 while 15.5 was the distance from sewage construction. Similarly, results from Industrial land-use type (tagged 11-12) revealed that the difference in depth between the highest and lowest is 3.5 , while the least height of the wells within this land use type is $7 \mathrm{~m}$. The range difference of the distance from sewage is $3 \mathrm{~m}$. Again all wells in this land-use type were constructed with concrete materials and uncovered, though with indicators that they were initially constructed with covers top. In the same vain, the results from residential land-use type (tagged R1-8) revealed that the highest depths were observed in Area 'B' Barrack, GRA with 10.2 feet's. Water sample with 'Code 026' from Church Compound, GRA emerges with $16 \mathrm{~m}$ above the earth surface and distance from sewage. Again all wells in this land use type were constructed with concrete materials and have mixed descriptive mode.

Results from Table 2 shows the collected data of water sample collected from the 3 selected land-uses types in the study area. Each of the Tables of 2a-c was attached with the WHO minimum and maximum standard limit for the examined water quality variables. The examined parameters to ascertain water quality were turbidity, dissolved oxygen (DO), total suspended solid (TSS), pH, electrical conductivity (EC), total dissolved solids (TDS), chloride $(\mathrm{Cl})$, sulphate $\left(\mathrm{SO}_{4}{ }^{2-}\right)$, nitrate $\left(\mathrm{NO}_{3}{ }^{-}\right.$ 
), phosphate $\left(\mathrm{PO}_{4}{ }^{3-}\right)$, calcium $(\mathrm{Ca})$, magnesium $(\mathrm{Mg})$, sodium $(\mathrm{Na})$ and potassium $(\mathrm{K})$. Table 3 shows the correlation and one-way analysis of variance (ANOVA) for the three land-uses types in Apapa.

Table 1: A Glimpse of the GIS and GPS of 30 water samples and their attributes

\begin{tabular}{|c|c|c|c|c|c|c|c|c|c|}
\hline \multirow[t]{2}{*}{$\mathrm{S} / \mathrm{N}$} & \multirow{2}{*}{$\begin{array}{l}\text { Water } \\
\text { Sample }\end{array}$} & \multirow[t]{2}{*}{ CODE } & \multirow[t]{2}{*}{ Location } & \multicolumn{2}{|c|}{ GPS Coordinate } & \multirow[t]{2}{*}{ Depth } & \multirow[t]{2}{*}{ Height } & \multirow[t]{2}{*}{ DTS } & \multirow{2}{*}{$\begin{array}{l}\text { Descriptive } \\
\text { Mode }\end{array}$} \\
\hline & & & & $\mathrm{X}$ & $\mathrm{Y}$ & & & & \\
\hline 1 & $\mathrm{C} 1$ & 001 & $\begin{array}{l}\text { Arakan } \\
\text { Barrack, } \\
\text { Boundary }\end{array}$ & 3.36420000000 & 6.46659000000 & $7.5 \mathrm{ft}$ & $14 \mathrm{~m}$ & $13 \mathrm{~m}$ & $\begin{array}{l}\text { Concrete; } \\
\text { Not } \\
\text { Covered }\end{array}$ \\
\hline 2 & $\mathrm{C} 2$ & 002 & $\begin{array}{l}\text { Arakan } \\
\text { Barrack, } \\
\text { Boundary }\end{array}$ & 3.36419000000 & 6.45163000000 & $8.8 \mathrm{ft}$ & $12 \mathrm{~m}$ & $14 \mathrm{~m}$ & $\begin{array}{l}\text { Concrete; } \\
\text { Not } \\
\text { Covered }\end{array}$ \\
\hline 3 & $\mathrm{C} 3$ & 003 & $\begin{array}{l}\text { Arakan } \\
\text { Barrack, } \\
\text { Boundary }\end{array}$ & 3.36892000000 & 6.44832000000 & $8.2 \mathrm{ft}$ & $13 \mathrm{~m}$ & $13 \mathrm{~m}$ & $\begin{array}{l}\text { Concrete; } \\
\text { Not } \\
\text { Covered }\end{array}$ \\
\hline 4 & $\mathrm{C} 4$ & 004 & $\begin{array}{l}\text { Arakan } \\
\text { Barrack, } \\
\text { Boundary }\end{array}$ & 3.36350000000 & 6.44871000000 & $8.0 \mathrm{ft}$ & $11 \mathrm{~m}$ & $12 \mathrm{~m}$ & $\begin{array}{l}\text { Concrete; } \\
\text { Not } \\
\text { Covered }\end{array}$ \\
\hline 5 & $\mathrm{C} 5$ & 005 & $\begin{array}{l}\text { Army Primary } \\
\text { School of } \\
\text { Education, } \\
\text { Boundary }\end{array}$ & 3.36952000000 & 6.44804000000 & $8.3 \mathrm{ft}$ & $12 \mathrm{~m}$ & $20 \mathrm{~m}$ & $\begin{array}{l}\text { Concrete; } \\
\text { Not } \\
\text { Covered }\end{array}$ \\
\hline 6 & C6 & 006 & $\begin{array}{l}\text { Army Primary } \\
\text { School of } \\
\text { Education, } \\
\text { Boundary }\end{array}$ & 3.37203000000 & 6.43751000000 & $8.9 \mathrm{ft}$ & $11 \mathrm{~m}$ & $21 \mathrm{~m}$ & $\begin{array}{l}\text { Concrete; } \\
\text { Not } \\
\text { Covered }\end{array}$ \\
\hline 7 & $\mathrm{C} 7$ & 007 & $\begin{array}{l}\text { Army Primary } \\
\text { School of } \\
\text { Education, } \\
\text { Boundary } \\
\end{array}$ & 3.37028000000 & 6.43711000000 & $8.8 \mathrm{ft}$ & $12 \mathrm{~m}$ & $20 \mathrm{~m}$ & $\begin{array}{l}\text { Concrete; } \\
\text { Not } \\
\text { Covered }\end{array}$ \\
\hline 8 & $\mathrm{C} 8$ & 008 & $\begin{array}{l}\text { Queen Barrack, } \\
\text { Boundary }\end{array}$ & 3.36223000000 & 6.44509000000 & $20.3 \mathrm{ft}$ & $11 \mathrm{~m}$ & $16 \mathrm{~m}$ & $\begin{array}{l}\text { Concrete; } \\
\text { Not } \\
\text { Covered }\end{array}$ \\
\hline 9 & C9 & 009 & $\begin{array}{l}\text { Queen Barrack, } \\
\text { Boundary }\end{array}$ & 3.35087000000 & 6.44388000000 & $21.4 \mathrm{ft}$ & $10 \mathrm{~m}$ & $10 \mathrm{~m}$ & $\begin{array}{l}\text { Concrete; } \\
\text { Not } \\
\text { Covered }\end{array}$ \\
\hline 10 & $\mathrm{C} 10$ & 010 & $\begin{array}{l}\text { Queen Barrack, } \\
\text { Boundary }\end{array}$ & 3.35807000000 & 6.44714000000 & $18.9 \mathrm{ft}$ & $5 \mathrm{~m}$ & $14 \mathrm{~m}$ & $\begin{array}{l}\text { Concrete; } \\
\text { Not } \\
\text { Covered }\end{array}$ \\
\hline 11 & I1 & 011 & Wharf, Apapa & 3.35396000000 & 6.44384000000 & $11.5 \mathrm{ft}$ & $11 \mathrm{~m}$ & $8 \mathrm{~m}$ & $\begin{array}{l}\text { Concrete; } \\
\text { Not } \\
\text { Covered }\end{array}$ \\
\hline 12 & $\mathrm{I} 2$ & 012 & Habour, Apapa & 3.35186000000 & 6.44486000000 & $12.0 \mathrm{ft}$ & $12 \mathrm{~m}$ & $8 \mathrm{~m}$ & $\begin{array}{l}\text { Concrete; } \\
\text { Not } \\
\text { Covered }\end{array}$ \\
\hline 13 & I3 & 013 & Wharf, Apapa & 3.35269000000 & 6.45060000000 & $13.5 \mathrm{ft}$ & $11 \mathrm{~m}$ & $7 \mathrm{~m}$ & $\begin{array}{l}\text { Concrete; } \\
\text { Not } \\
\text { Covered }\end{array}$ \\
\hline 14 & I4 & 014 & Wharf, Apapa & 3.37633000000 & 6.43954000000 & $13.5 \mathrm{ft}$ & $8 \mathrm{~m}$ & $6 \mathrm{~m}$ & $\begin{array}{l}\text { Concrete; } \\
\text { Not } \\
\text { Covered }\end{array}$ \\
\hline 15 & I5 & 015 & $\begin{array}{l}\text { Burman Road, } \\
\text { Apapa }\end{array}$ & 3.37373000000 & 6.43780000000 & $13.6 \mathrm{ft}$ & $7 \mathrm{~m}$ & $8 \mathrm{~m}$ & $\begin{array}{l}\text { Concrete; } \\
\text { Not } \\
\text { Covered }\end{array}$ \\
\hline 16 & I6 & 016 & $\begin{array}{ll}\text { Creek Road, } \\
\text { Apapa }\end{array}$ & 3.36822000000 & 6.43586000000 & $13.9 \mathrm{ft}$ & $9 \mathrm{~m}$ & $7 \mathrm{~m}$ & $\begin{array}{l}\text { Concrete; } \\
\text { Not } \\
\text { Covered }\end{array}$ \\
\hline 17 & I7 & 017 & Wharf, Apapa & 3.36937000000 & 6.44105000000 & $13.7 \mathrm{ft}$ & $8 \mathrm{~m}$ & $5 \mathrm{~m}$ & $\begin{array}{l}\text { Concrete; } \\
\text { Not } \\
\text { Covered } \\
\end{array}$ \\
\hline 18 & I8 & 018 & $\begin{array}{l}\text { Dockyard, } \\
\text { Apapa }\end{array}$ & 3.37249000000 & 6.44213000000 & $12.7 \mathrm{ft}$ & $9 \mathrm{~m}$ & $6 \mathrm{~m}$ & $\begin{array}{l}\text { Concrete; } \\
\text { Not } \\
\text { Covered }\end{array}$ \\
\hline 19 & I9 & 019 & Wharf, Apapa & 3.37239000000 & 6.44242000000 & $10.4 \mathrm{ft}$ & $8 \mathrm{~m}$ & $6 \mathrm{~m}$ & $\begin{array}{l}\text { Concrete; } \\
\text { Not } \\
\text { Covered }\end{array}$ \\
\hline 20 & $\mathrm{I} 10$ & 020 & $\begin{array}{l}\text { Dockyard, } \\
\text { Apapa }\end{array}$ & 3.37183000000 & 6.44757000000 & $13.7 \mathrm{ft}$ & $9 \mathrm{~m}$ & $8 \mathrm{~m}$ & $\begin{array}{l}\text { Concrete; } \\
\text { Not } \\
\text { Covered }\end{array}$ \\
\hline
\end{tabular}




\begin{tabular}{|c|c|c|c|c|c|c|c|c|c|}
\hline \multirow[t]{2}{*}{$\mathrm{S} / \mathrm{N}$} & \multirow{2}{*}{$\begin{array}{l}\text { Water } \\
\text { Sample }\end{array}$} & \multirow[t]{2}{*}{ CODE } & \multirow[t]{2}{*}{ Location } & \multicolumn{2}{|c|}{ GPS Coordinate } & \multirow[t]{2}{*}{ Depth } & \multirow[t]{2}{*}{ Height } & \multirow[t]{2}{*}{ DTS } & \multirow{2}{*}{$\begin{array}{l}\text { Descriptive } \\
\text { Mode }\end{array}$} \\
\hline & & & & $\mathrm{X}$ & $\bar{Y}$ & & & & \\
\hline 21 & R1 & 021 & $\begin{array}{l}\text { Tamade } \\
\text { Barrack, GRA }\end{array}$ & 3.36438000000 & 6.44717000909900 & $0000^{5 \mathrm{ft}}$ & $8 \mathrm{~m}$ & $12 \mathrm{~m}$ & $\begin{array}{l}\text { Concrete; } \\
\text { Not } \\
\text { Covered }\end{array}$ \\
\hline 22 & $\mathrm{R} 2$ & 022 & $\begin{array}{l}\text { Tamade } \\
\text { Barrack, GRA }\end{array}$ & 3.37315000000 & 6.44487000000 & $8.8 \mathrm{ft}$ & $12 \mathrm{~m}$ & $7 \mathrm{~m}$ & $\begin{array}{l}\text { Concrete; } \\
\text { Not } \\
\text { Covered }\end{array}$ \\
\hline 23 & R3 & 023 & $\begin{array}{l}\text { Tamade } \\
\text { Barrack, GRA }\end{array}$ & 3.36813000000 & 6.44261000000 & $8.7 \mathrm{ft}$ & $7 \mathrm{~m}$ & $8 \mathrm{~m}$ & $\begin{array}{l}\text { Concrete; } \\
\text { Not } \\
\text { Covered }\end{array}$ \\
\hline 24 & $\mathrm{R} 4$ & 024 & $\begin{array}{l}\text { Tamade } \\
\text { Barrack, GRA }\end{array}$ & 3.36452000000 & 3.36452000000 & $8.6 \mathrm{ft}$ & $7 \mathrm{~m}$ & $7 \mathrm{~m}$ & $\begin{array}{l}\text { Concrete; } \\
\text { Not } \\
\text { Covered }\end{array}$ \\
\hline 25 & R5 & 025 & $\begin{array}{l}\text { Tamade } \\
\text { Barrack, GRA }\end{array}$ & 3.35249000000 & 6.44035000000 & $8.6 \mathrm{ft}$ & $9 \mathrm{~m}$ & $10 \mathrm{~m}$ & $\begin{array}{l}\text { Concrete; } \\
\text { Not } \\
\text { Covered }\end{array}$ \\
\hline 26 & R6 & 026 & $\begin{array}{l}\text { Church } \\
\text { Compound, } \\
\text { GRA }\end{array}$ & 3.35766000000 & 6.44989000000 & $9.9 \mathrm{ft}$ & $16 \mathrm{~m}$ & $16 \mathrm{~m}$ & $\begin{array}{l}\text { Concrete, } \\
\text { Covered }\end{array}$ \\
\hline 27 & $\mathrm{R} 7$ & 027 & $\begin{array}{l}\text { Church } \\
\text { Compound, } \\
\text { GRA }\end{array}$ & 3.35116000000 & 6.44264000000 & $9.9 \mathrm{ft}$ & $16 \mathrm{~m}$ & $13 \mathrm{~m}$ & $\begin{array}{l}\text { Concrete, } \\
\text { Covered }\end{array}$ \\
\hline 28 & $\mathrm{R} 8$ & 028 & $\begin{array}{l}\text { Area 'B' } \\
\text { Barrack, GRA }\end{array}$ & 3.36399000000 & 6.45114000000 & $10.2 \mathrm{ft}$ & $11 \mathrm{~m}$ & $8 \mathrm{~m}$ & $\begin{array}{l}\text { Concrete; } \\
\text { Not } \\
\text { Covered }\end{array}$ \\
\hline 29 & I11 & 029 & $\begin{array}{l}\text { Dockyard, } \\
\text { Apapa }\end{array}$ & 3.36024000000 & 6.45012000000 & $12.5 \mathrm{ft}$ & $8 \mathrm{~m}$ & $12 \mathrm{~m}$ & $\begin{array}{l}\text { Concrete; } \\
\text { Not } \\
\text { Covered }\end{array}$ \\
\hline 30 & $\mathrm{I} 12$ & 030 & $\begin{array}{ll}\text { Creek Road, } \\
\text { Apapa }\end{array}$ & 3.34287000000 & 6.43224000000 & $13.7 \mathrm{ft}$ & $9 m$ & $13 \mathrm{~m}$ & $\begin{array}{l}\text { Concrete; } \\
\text { Not } \\
\text { Covered }\end{array}$ \\
\hline
\end{tabular}

Source: Field Survey, 2020

Table 1 show at a glance all the 30 water samples collection, their spatial geographical locations and coordinates, depth and height of wells, distance from sewage, and descriptive modes of the 3 selected land use types of the study area.

Table 2a: Physical and chemical characteristics of groundwater quality in commercial land-use area of Apapa

\begin{tabular}{|l|c|c|c|c|c|c|c|c|c|c|c|c|c|c|}
\hline Variable & $\mathrm{T}$ & $\mathrm{DO}$ & $\mathrm{TSS}$ & $\mathrm{PH}$ & $\mathrm{EC}$ & $\mathrm{TDS}$ & $\mathrm{Cl}$ & $\mathrm{SO}_{4}{ }^{2-}$ & $\mathrm{NO}_{3^{-}}$ & $\mathrm{PO}_{4}{ }^{3-}$ & $\mathrm{Ca}$ & $\mathrm{M}_{\mathrm{g}}$ & $\mathrm{Na}$ & $\mathrm{K}$ \\
\hline WHO & 2.5 & 3.0 & 3.0 & 8.5 & 1000 & 500 & 250 & 4.0 & 10 & 0.03 & & & & \\
\hline 1 & 0 & 6.4 & $\mathrm{ND}$ & 7.1 & 392 & 260 & 10 & 12 & 3.15 & 0.02 & 14 & 8 & 6.11 & 1.72 \\
\hline 2 & 0 & 6.3 & $\mathrm{ND}$ & 7.2 & 392 & 263 & 8 & 12 & 3.2 & 0.02 & 14 & 6 & 4.56 & 1.39 \\
\hline 3 & 0 & 5.2 & $\mathrm{ND}$ & 7.2 & 275 & 184 & 10 & 8 & 2.19 & 0.01 & 10 & 6 & 5.89 & 1.4 \\
\hline 4 & 4 & 5.7 & 5 & 7.3 & 1030 & 683 & 212 & 23 & 6.3 & 0.03 & 34 & 12 & 102.12 & 18.32 \\
\hline 5 & 7 & 5.8 & 9 & 7.3 & 1277 & 859 & 350 & 33 & 10.8 & 0.05 & 42 & 14 & 120.3 & 18.32 \\
\hline 6 & 2 & 6.2 & 2 & 7.3 & 288 & 194 & 14 & 10 & 2.35 & 0.01 & 10 & 4 & 7.08 & 2.54 \\
\hline 7 & 2 & 6.1 & 3 & 7.2 & 496 & 332 & 14 & 14 & 3.72 & 0.02 & 12 & 4 & 6.96 & 2.38 \\
\hline 8 & 0 & 6.3 & 2 & 7.2 & 534 & 357 & 16 & 14 & 3.8 & 0.02 & 12 & 6 & 7.38 & 2.71 \\
\hline 9 & 10 & 6 & 12 & 7.2 & 1294 & 871 & 38 & 42 & 9.25 & 0.05 & 44 & 10 & 192.06 & 38.5 \\
\hline 10 & 0 & 6.4 & ND & 7.1 & 572 & 382 & 20 & 18 & 4.63 & 0.04 & 14 & 6 & 7.7 & 2.59 \\
\hline
\end{tabular}

Source: Fieldwork, 2020

Table 2b: Physical and chemical characteristics of groundwater quality in residential land-use area of

\begin{tabular}{|l|c|c|c|c|c|c|c|c|c|c|c|c|c|c|}
\hline Variable & T & DO & TSS & PH & E C & TDS & Cl & SO $_{4}{ }^{2-}$ & $\mathrm{NO}_{3^{-}}$ & $\mathrm{PO}_{4}{ }^{3-}$ & $\mathrm{Ca}$ & $\mathrm{M}_{\mathrm{g}}$ & $\mathrm{Na}$ & $\mathrm{K}$ \\
\hline WHO & 2.5 & 3.0 & 3.0 & 8.5 & 1000 & 500 & 250 & 4.0 & 10 & 0.03 & & & & \\
\hline 21 & 0 & 6.4 & ND & 7.1 & 392 & 260 & 10 & 12 & 3.15 & 0.02 & 14 & 8 & 6.11 & 1.72 \\
\hline 22 & 0 & 6.3 & ND & 7.2 & 392 & 263 & 8 & 12 & 3.2 & 0.02 & 14 & 6 & 4.56 & 1.39 \\
\hline 23 & 0 & 5.2 & ND & 7.2 & 275 & 184 & 10 & 8 & 2.19 & 0.01 & 10 & 6 & 5.89 & 1.4 \\
\hline 24 & 4 & 5.7 & 5 & 7.3 & 1030 & 683 & 212 & 23 & 6.3 & 0.03 & 34 & 12 & 102.12 & 18.32 \\
\hline 25 & 7 & 5.8 & 9 & 7.3 & 1277 & 859 & 350 & 33 & 10.8 & 0.05 & 42 & 14 & 120.3 & 18.32 \\
\hline 26 & 2 & 6.2 & 2 & 7.3 & 288 & 194 & 14 & 10 & 2.35 & 0.01 & 10 & 4 & 7.08 & 2.54 \\
\hline 27 & 2 & 6.1 & 3 & 7.2 & 496 & 332 & 14 & 14 & 3.72 & 0.02 & 12 & 4 & 6.96 & 2.38 \\
\hline 28 & 0 & 6.3 & 2 & 7.2 & 534 & 357 & 16 & 14 & 3.8 & 0.02 & 12 & 6 & 7.38 & 2.71 \\
\hline
\end{tabular}


Table 2c: Physical and chemical characteristics of groundwater quality in industrial land-use area of

\begin{tabular}{|l|c|c|c|c|c|c|c|c|c|c|c|c|c|c|}
\hline Variable & T & D O & TSS & PH & E C & TDS & Cl & $\mathrm{SO}_{4}{ }^{-2}$ & $\mathrm{NO}_{3-}{ }^{-}$ & $\mathrm{PO}_{4}{ }^{3-}$ & $\mathrm{Ca}$ & $\mathrm{M}_{\mathrm{g}}$ & $\mathrm{Na}$ & $\mathrm{K}$ \\
\hline WHO & 2.5 & 3.0 & 3.0 & 8.5 & 1000 & 500 & 250 & 4.0 & 10 & 0.03 & & & & \\
\hline 11 & 2 & 6.3 & 2 & 7.1 & 542 & 363 & 34 & 16 & 4.48 & 0.03 & 16 & 4 & 6.98 & 1.55 \\
\hline 12 & 0 & 6.4 & $\mathrm{ND}$ & 7.1 & 545 & 364 & 38 & 16 & 4.49 & 0.04 & 14 & 6 & 7.92 & 2.6 \\
\hline 13 & 2 & 6.2 & 3 & 7.2 & 842 & 564 & 76 & 26 & 7.22 & 0.04 & 30 & 8 & 15.77 & 6.18 \\
\hline 14 & 3 & 6 & 2 & 7.2 & 848 & 568 & 110 & 27 & 7.47 & 0.05 & 34 & 8 & 45.63 & 10.32 \\
\hline 15 & 2 & 6.2 & 2 & 7.3 & 850 & 590 & 108 & 27 & 6.98 & 0.05 & 34 & 6 & 40.94 & 9.86 \\
\hline 16 & 0 & 6.4 & ND & 7.3 & 884 & 593 & 30 & 31 & 7.54 & 0.04 & 38 & 8 & 14.58 & 3.49 \\
\hline 17 & 2 & 6.2 & 2 & 7.3 & 879 & 588 & 40 & 30 & 7.5 & 0.04 & 34 & 8 & 16.89 & 3.97 \\
\hline 18 & 2 & 5.9 & 2 & 7.2 & 872 & 583 & 56 & 30 & 7.5 & 0.04 & 32 & 6 & 25.28 & 5.47 \\
\hline 19 & 3 & 5.8 & 2 & 7.1 & 881 & 588 & 44 & 31 & 7.49 & 0.04 & 36 & 6 & 27.92 & 6.02 \\
\hline 20 & 0 & 6.1 & ND & 7.2 & 880 & 588 & 82 & 29 & 7.52 & 0.05 & 38 & 6 & 36.17 & 8.51 \\
\hline 29 & 2 & 5.8 & 2 & 7.3 & 1642 & 1100 & 460 & 48 & 12.39 & 0.06 & 52 & 16 & 210.16 & 31.92 \\
\hline 30 & 13 & 5.4 & 25 & 7.4 & 1191 & 797 & 200 & 37 & 9.18 & 0.05 & 46 & 10 & 81.52 & 19.6 \\
\hline
\end{tabular}

Source: Fieldwork, 2020

Results from Tables 2a-c shows the laboratory analysis for groundwater quality in the 3 most landuse types; industrial, commercial and residential of Apapa. From the Tables of 2a-c, Electrical Conductivity for Industrial landuse was above the maximum standard limit of 1000 in Queen Barrack, Boundary (1642), Creek Road, Apapa (1191). From the Residential landuse type in Tamade Barrack, GRA were (1030 and 1277). Electrical Conductivity was only above the limit in one location from the Commercial land use type, Queen Barrack, Boundary (1294). It was observed that increase in EC directly linked with the TDS. Furthermore, some areas have their TDS higher above the standard limit of 500. From the Industrial land use, both Dockyard and Creek Road have TDS values of 1100 and 797. In the Residential land use type, Tamade, Barrack, GRA has (68-859) and Queen Barrack, Boundary has (871) for the Commercial area. Laboratory data were subjected to descriptive analysis which were mean, minimum, maximum, standard deviation and coefficient of variation.

The minimum value ranged from zero (turbidity) to $275(\mathrm{EC})$, mean also ranged from $0.03\left(\mathrm{PO}_{4}{ }^{3-}\right)$ to 743.31 (EC), minimum were between $0.06\left(\mathrm{PO}_{4}{ }^{3-}\right)$ to 1642 (EC). Dissolved Oxygen (5.66) accounts for the lowest computed value and magnesium (230.28) accounts for the coefficient of variation. In view of the above discussions, the relevance of mapping and sampling of land-use types on groundwater quality in Apapa Local Government area, Lagos revealed that mapping of an area enables one to make plotting of the aerial and ground diagrams, make observes and projections of the earthly features of geographical information system and global positioning system of the aerial extent of an area such as Apapa which serves as the conveyor of the research process. To this end, mapping of the aerial extent must be delineated because it's the focus of the study area and in defining the problems, purpose, scope and methods of data collection and collation. In addition, mapping provides a framework for any given geographical research. it's serves as a guide and gives directions. It provides all physical and cultural features of a place to accomplish a research work. Furthermore, mapping is synonymous with study area in the sense that the map of the area functions as a laboratory, a workshop, a domain or an atlas where primary data of raw information can be obtained, process and transformed to facts and findings. Mapping has to be confided within the coordinates of GIS and GPS as shown in Figures 2.1 to 2.4. On the other hand, sampling of an area enables the researcher to have results, decision and projections about a problem identify after series of analyses from the samples collations about a cross sections of problem identify as in the case of this study. Furthermore, sampling enables the researcher to have details knowledge about the problem identified and methods to go about it. For instance, the physical and chemical parameters of water samples collected from the 30 hand-dug wells for this study were subjected to laboratory analyses to ascertain water standard and suitability for human uses (An-ion and Cat-ion) in line with the recommended standards of WHO on water quality. 
Table 3: Correlation and one-way analysis of variance (ANOVA) for the three land-uses types in Apapa

Variables
Tukey HSD
\begin{tabular}{|l|l|c|c|c|c|c|}
\hline \multirow{3}{*}{ (I) Code } & & Mean Difference & & & \multicolumn{2}{|c|}{$95 \%$ Confidence Interval } \\
\cline { 3 - 7 } & (J) Code & -34.13071 & 83.34680 & .912 & -237.1892 & 168.9277 \\
\hline Commercial Land use & Residential Land use & Std. Error & Sig. & Lower Bound & Upper Bound \\
\cline { 2 - 7 } & Industrial Land use & 9.10071 & 83.34680 & .993 & -193.9577 & 212.1592 \\
\hline \multirow{2}{*}{ Residential Land use } & Commercial Land use & 34.13071 & 83.34680 & .912 & -168.9277 & 237.1892 \\
\cline { 2 - 7 } & Industrial Land use & 43.23143 & 83.34680 & .863 & -159.8270 & 246.2899 \\
\hline Industrial Land use & Commercial Land use & -9.10071 & 83.34680 & .993 & -212.1592 & 193.9577 \\
\cline { 2 - 7 } & Residential Land use & -43.23143 & 83.34680 & .863 & -246.2899 & 159.8270 \\
\hline
\end{tabular}

Source: Fieldwork, 2020

\subsection{Conclusion}

Mapping connotes plotting of aerial and ground diagrams with geo-informatics tools of geographical information system, global positioning system and remote sensing. Sampling connotes the act of gathering, observation, processes and analysis of collected samples from an identify problem. Mapping shows physical and cultural features about a place such as title, aerial extent, coordinates, description of features, scale and direction while sampling depicts collection of sample materials for examination, decision and projection for a problem solve. To this end, mapping and sampling provides details knowledge about a problem identified, methods and analysis of results. There is a linkage between mapping and sampling for a problem solve. The state of the land use types to a large extent determines the state of water quality. The processes of infiltration, seepages and laches of contaminated substances and pollutants are added factors to groundwater quality. Sampling of water sources is essentials to ascertain water quality and suitability for human consumption. Those in Industrial land use type and coastal areas should dig their hand-dug wells beyond water table, may be up to $3^{\text {rd }}$ and $4^{\text {th }}$ layer of the aquifers for quality and regular water supply. This is due to the high level of seepages, infiltration and flows of pollutants from physicochemical and biological parameters associated with high-prowl areas like Apapa. Furthermore, in areas where hand-dug wells are to be constructed to complement the efforts of water supply, mapping of the aerial and ground extent as well as sampling of water parameters needs to be carried out. This is to ascertain an ideal site of location, drilling methods and depths, which should be curtained by geographical information and hydro-geologist experts as this will enhance site location and quality of water supply. The study recommends that at regular intervals, ground water maps and sampling of water sources need to be carried out and made available to researchers and agencies to examine groundwater flow lines that determines contamination of water points and also where aquifers are being overdrawn or a combination of the above.

\section{References}

Adekanbi, E.O. (1979). A study of the industrial effluents and waste disposal habits of some industrial discharging directly into the Lagos Lagoon.

Adelegan, J.A. (2004). The history of environmental pollution of water source in Nigeria (19602004); The Way Forward; University of Ibadan.

Aderibigbe, S.A, Awoyemi, A.O and Osagbemi, G.K. (2008). Availability, adequacy and quality of water supply in Ilorin metropolis, Nigeria. Eur.J. Scientific Res. pp. 528-536.

Adekunle, I.M. (2007). Assessment of groundwater quality in a tropical rural settlement in Southwest Nigeria. International Journal of Environmental Research and Public Health, 4(4), pp. 307-318.

Agbebaku, H.U. (2014). Analysis of ground-water quality under varied land-uses; a case study of Apapa Local Government Area, Lagos State. An M.Sc. Thesis Presented to the Department of Geography and Regional Planning, Lagos State University, Ojo. 
Agbebaku, H.U. (2020). Water quality assessment of hand-dug wells in Apapa Local Government Area of Lagos State. Osun Geographical Review, Journal of the Department of Geography, Osun State University, State of Osun, Nigeria, 2(1).

Akoteyon, I.S and Soladoyin, O. (2011). Ground water quality assessment in Eti-Osa, Lagos Nigeria using multivariate analysis.

Akoteyon, I.S. (2011). Ground water quality assessment in Eti-Osa, Lagos, Nigeria. [online] Journal of Tropical Ecology.18, pp. 300-331 Www.Ajol.Info/Indes.Phpjasen. Retrieved November, 30 2015.

APHA, AWWA, WEF, (1992). Standard methods for the examination of water and wastewater, American Public Health Association, Washington, D.C.

APHA. (1992). Standard methods for the examination of water and wastewater.18 $18^{\text {th }}$ Ed. American Public Health Association, Washington, DC.

Aronoff, S. (1989). Geographic information system. a management perspective. Ottawa; W.D.L. Publication.

Brooker, S., Rowlands, M., Haller, L., Savioli, L and Bundy, D.A.P. (2000). Toward an atlas of human helminth infection in Sub-Saharan African; The Use of Geographic Information System (GIS) Parasitology Today, 16(7).

Campbell, J.B. (2002). Introduction to remote sensing; $3^{\text {rd }}$ Edition, New York. Guilford Press.

Cannor, R.A., Kralewski, J.E and Hillson, S.D. (1994). Measuring geographic access to health care in rural areas. Medical Care Review, 51(3), 33-47.

Chapman, D. (1992). Water quality assessment, a guide to be use of biota, sediments and water in environmental monitoring- Second Edition, Published on E \& FN Spon, An Impact of Chapman and Hall.

Chapman, D. (1996). Water quality assessment; A guide to be use of biota, sediments and water in environmental monitoring. London; Chapman and Hall, 585.

Christopherson, R.W. (2007). Elemental geosystem, fifth edition, Person Prentice Hall Upper Saddle River.

Edobor, W.W. (2016). Geoformatic-based spatio-temporal analysis of the prevalence of diarrhoea diseases in Esan Land, Edo State, Nigeria. A Ph.D. Research Proposal Presented to the Department of Geography and Environmental Management, Ambrose Alli University, Ekpoma, Edo State.

Eludoyin, A.O. (2010). Introduction to instrumentation measurement and field methods in environmental science, ESM 341 Course Material of the National Open University of Nigeria, Abuja.

FEPA (1991). Guidelines and standards for environmental pollution control in Nigeria, pp. 54-55 Federal Environmental Protection Agency, Ministry of Environment, Nigeria

FGN (2000). Water supply and interim strategy note, Federal Government of Nigeria,

FGN (1993). Nigeria: water resources Decree 1993, Decree No.101. [online] Available at: www.ielrc.org/content/e9302.pdf. [Accessed 17th June, 2010].

FGN (2000). Water supply \& interim strategy note. Federal Government of Nigeria. [online] Available at: http://siteresources.worldbank.org/NIGERIAEXTN/Resources/wss_1100.pdf. [Accessed 17th June, 2010].

FMWR, (2007). Federal ministry of water resources; Organisation and Activities, Federal Republic of Nigeria 
Gohil, M.B. (2007). Land treatment of water; New Age International Publishers

Guidelines for drinking-water quality, 3rd Edition, Vol. 1: Recommendations/Japanese Version [Pdf $4.44 \mathrm{Mb}]$

Guidelines for drinking-water quality, Vol. 1, 3rd Edition Incorporating 1st and 2nd Addenda Pdf, $3.26 \mathrm{Mb}$

Iyun, B.F. (1990). Hierarchical spatio-temporal mapping of disease rates. Journal of American Statistical Association 92, 607-617.

Lagos State Water Corporation, (LSWC, 2013). [online] website http; //www. Lagos water .com

NESREA, (2008). About NESREA, National Environmental Standards and Enforcements Agency, Abuja.

Ojeifo, O.M and Kadiri, M.A. (2008). Analysis of spatial pattern and prevalence of water related disease in Owan East Local Government of Edo State; A Case Study of Otuo and Environs. GRP Journal of Environmental Planning and Management, 1, 5-15.

Oluleye, E.K and Rilwani, M.1. (2011). Mapping of the growth and development of Zaria suburbs using remote sensing and geographical information system. GRP Journal of Environmental Planning and Management. Ambrose Alli University, Ekpoma, Nigeria, 4.

Omofonmwan, S.I. (1992). Indicators for measuring the quality of life in rural areas. A case study of Orhionmwon Local Government of Bendel State. Nigeria Journal of Social Science 1(1), 45-52.

Ozebo, V.C and Ajiroba, S.O. (2011). Ground water assessment in Apapa coastal line area of Lagos using electrical resistivity method.

Soladoye, O.Y. (2013). Unpublished lecture notes on water resources management GRP844, Lagos State University, Ojo Lagos

Strahler, A and Strahler, A. (2006). Introducing physical geography, 4 Edition, John Wiley and Sons Inc.

Uluocha, N.O. (2015). Research methods in geography and environmental sciences, Lagos, Sam Iroanusi Publications

Water World Health Organization, (WHO, 2004). Guidelines for drinking water quality. $3^{\text {rd }}$ Edn.Vol.1 recommendation, Geneva, 515

Wesrcott, B. (1999). GIS and GPS- The backbone of vermont; Statewide E911 Implementation, PE and RS 2(65), 1269-1276.

World Health Organization (WHO, 2005). Guidelines for drinking water and quality, $2^{\text {nd }}$ Edition, 1 , Recommendations. Geneva; Who, 2005, 49-50

World Health Organization (WHO, 2009). Safe, better health, WHO, [online] <http;//www.who.int/quantifying_ehimpacts/publications/saferwater/en/index.html>, Retrieved November, 2015.

Wright, R.T and Boorse, D.F. (2011). Environmental science: Toward a Sustainable Future: Eleven Edition: International Edition: Unit 10.

\section{Cite this article as:}

Agbebaku H. U., 2021. An Assessment of the Relevance of Mapping and Sampling of Land-Use Types on Groundwater Quality in Apapa Local Government Area, Lagos State, Nigeria. Nigerian Journal of Environmental Sciences and Technology, 5(2), pp. 307-319. https://doi.org/10.36263/nijest.2021.02.0234 